\title{
The Influence of Techno stress and Organizational-Is Related Support on User Satisfaction in Government Organizations: A Proposed Model and Literature Review
}

\author{
${ }^{*}$ Hadziroh Ibrahim ${ }^{1}$, Yusliza Mohd Yusoff ${ }^{2}$, Nur Zahiyah Othman² \\ 1Universiti Utara Malaysia, Malaysia \\ 2Universiti Sains Malaysia, Malaysia \\ *hadziroh@uum.edu.my
}

\begin{abstract}
Empirical evidence on the issue of satisfaction towards certain computer applications or systems has guided organizations in the implementation process of information systems (IS). What is more important, findings of the previous studies in the IS field have proved that user satisfaction is one dimension of IS success and needs to be carefully managed during the implementation process. Consequently, organizations are increasingly concerned about ensuring that employees have gained satisfaction about the IS that they use. Organizations also need to investigate user opinions about the system, and where its faults lie. Though there are a great number of studies on IS, little attention has been given to the influence of technostress and organizational IS-related support on IS success in government organizations of Malaysia. Two hypotheses were generated from the previous studies which link technostress, organizational IS-related support with user satisfaction. These hypotheses will be tested in the future. The results from the research would contribute useful insights in EHRM studies. Particularly, the results would help the government organizations in Malaysia to improve their implementation of HRMIS.
\end{abstract}

Key words: EHRM, techno stress, IS-support, user satisfaction, HRMIS, Malaysia

\section{Introduction}

Internet booming since two decade ago has called researchers to utilize the technology to enhance the efficiency and effectiveness of any transactions and process in organizations (Rawash \& Saydam, 2012). The technology enhancement in Human Resource Management (HRM) has improved the operations of HRM practices, its strategies, and policies. The application of technology into HRM is often called as electronic HRM (EHRM). Previous studies have provides empirical and subjective results on the outcome of EHRM toward the HR functions, employees, and organizations. Bell, Lee and Yeung (2006) found that the transactions cost of HRM can be reduced up to 75 percent and regain cost associated with the eapplication can be captured in less than two year. In another study, EHRM has helped work flexibility among employees. Employees able to work from different locations and reported to the same HR Department through the applications of video, e-mail, and internet (Noe, Hollenbeck, Gehart \& Wright, 2008). In addition, according to the study, EHRM enable recruiting of work providing training, taking test in talent's selection, reviewing salary and bonus information online. Shilpa and Gopal (2011) argued that EHRM would better facilitates the management of all the important competitive edge, particularly for the activities that involves generating of ideas, formation of thinking and the serving the HR's customers.

The continued consensus of the technology application in HRM is that whether employees are satisfied as it is considered to be surrogated for Information System (IS) success (Baroudi, Olson \& Ives, 1986; Gudigantala, Song \& Jones, 2011; Igbaria \& Nachman, 1990; Ives, Olson \& Baroudi, 1983; Sabherwal, Teyaraj \& Chowa, 2006). Employees' satisfaction is seen as a predictor to run HRM smoothly in organization (Gupta \& Saxen, 2011). Thus, organization need to first investigate the users' opinion regarding the systems applied in the HRM. Some studies have made attempts to understand the extent of users' satisfaction on IS and the predictors (i.e., Aggelidis \& Chatzoglou, 2012; Bhattacherjee, 2001; Dastgir \& Mortezaie, 2012; DeLone \& McLean, 1992; Gudigantala et al., 2011; Larsen, 2009; McKinney, Yoon \& Zahedi, 2002; Nadkarni \& Gupta, 2007; Oliver \& Richard, 1980; Tarafdar, Tu \& Ragu-Nathan, 2011; Venkatesh, Morris, Davis \& Davis, 2003). However, much more efforts must be made by scholars, researchers, and practitioners to ensure the e-applications' success in HRM. In order to investigate the antecedents of users' satisfaction, the present study provides a framework inspired from Tarafdar, Tu, Ragu-Nathan, and Ragu-Nathan (2011)'s work. The researchers applied the model to examine the 
influence of stress conditions and organizational mechanisms on job outcomes and it is adapted from the Transaction Theory of Stress by Lazarus (as cited by Tarafdar et al., 2011).

The Human Resource Management Information System (HRMIS) in Malaysia: The government of Malaysia is not exempt from making investments of technology in human resource activities. Under the electronic government (EG) projects, human resource management information systems (HRMIS) is introduced to provide public servants with an integrated system for human resource information management. Eia (2004) noted that the HRMIS project is implemented in tandem with the government's vision in using information and communication technology (ICT) to transform the operations of human resource processes and subsequently propel the country into the era of the knowledge worker and the knowledge based economy. The project was scheduled to be implemented in two phases. Phase 1 involved the development and implementation of HRMIS core applications at 10 pilot agencies that represent the Malaysian government structure at the federal, state, and local government levels. The ten pilot agencies were Public Service Department (PSD), Kuala Lumpur City Hall (DBKL), the Ministry of Health, Department of Chief Minister of Sarawak, Department of Irrigation and Drainage (DID), Perbadanan Kemajuan Negeri Selangor (PKNS), Majlis Amanah Rakyat (MARA), Chief Executive of the Management Information System (SMPKE), Unit Administrative Modernization and Management Planning (MAMPU), and the Department of Veterinary Services (DVS) (Public Service Department, 2010). Phase 1 started on 12 April 1999 and was completed on September in the same year. Phase 2 involves the rolling out of the HRMIS application to the rest of the government agencies nationwide. Now, the application of HRMIS still in the rolling out process to the rest of the government agencies with additional enhancement made to the application from time to time. All documents on HRMIS such as corporate information, implementation policies, standard operation of procedures, and customer services can be accessed from http://www.eghrmis.gov.my/. The implementation of HRMIS is fully monitored by Public Service Department (PSD) of Malaysia as the lead agency. According to MAMPU (2003, as cited by McPherson \& Ramli, 2004, p. 709), the HRMIS specifically aims for the following:

- effective staffing and rightsizing of the civil service through better availability of HRM information;

- automating the HRM operational processes which are currently done manually;

- providing up-to-date consolidated HRM information for effective HRM planning among agencies;

- better communication, horizontal integration and more streamlined processes through establishing a richer collaborative system environment among the agencies so as to provide a single window access to HRM transactions that cut across agencies;

- improving paper-less HRM capabilities among agencies such as electronic distribution of human resource policy manuals and circulars electronically; and

- providing an open and flexible system to fulfil and improve the information needs of operational and managerial processes at different levels of agencies.

HRMIS Research Problem: On March 2012, the government instructed the Public Service Department (PSD) of Malaysia and Malaysian Administrative Modernization and Management Planning Unit (MAMPU) to re-develop and upgrade the HRMIS, called HRMIS2. As stated in the service circular, ${ }^{1}$ the main reason for doing so was mainly due to the unfavorable responses among users towards HRMIS. In the other words, majority of HRMIS users were not satisfied with the applications. Following that, a survey was conducted by the PSD and MAMPU on HRMIS2. It was found that almost 50 percent of the HRMIS2 users were still not satisfied with the system. ${ }^{2}$ Because HRMIS is an important IS application for users in the public sector organizations and the government is the main machinery of the national development, studying the effectiveness of IS and HRMIS in particular is thus warranted. Furthermore, Aladwani (2003) $\mathrm{Au}$, Ngai, and Cheng (2002), and Guimaraes and Igbaria (1997) mentioned that system's factors, user's situational factors or behavioural factors, and social factors or organizational factors have significant impacts on user satisfaction. A number of studies claimed that most systems fail to fulfil the objectives and outcomes held for them, not because they do not have technical skills, but because psychological and organizational issues are not well tackled during the development and implementation stages (Au \& Ngai, 2008). Several attempts were reported to investigate the HRMIS from various contexts and issues (MAMPU, 2011; McPherson \& Ramli, 2004; Mohd Azman, 2011; Noraswati, 2011; Norshita, Halimah \& Tengku Mohammad, 2010). Only a few of them tried to investigate the issue of satisfaction among users towards HRMIS. Therefore, the main objective of the study is to examine the user satisfaction towards

\footnotetext{
${ }^{1}$ http://www.eghrmis.gov.my

${ }^{2}$ The result of the survey can be accessed here: http://www.eghrmis.gov.my/index.php/home/makluman-semasa/item/353-sesidialog-hrmis-2012.html
} 
HRMIS in public sector, particularly on the influence of technostress and organizational IS-related support. The contributions of the study include the theoretical contribution to the IS success literature, contribution to the field of EHRM or HRIS, and contribution by examining the influence of technostress and organizational support factors on user satisfaction. The outcome of the research could be used to assist in the implementation of EHRM in organizations, particularly HRMIS in government organizations. A research model is proposed using factors identified from the literature review.

\section{Literature Review}

Electronic Human Resource Management (EHRM): Technology applications in HRM in previous studies has been termed interchangeably between electronic HRM (EHRM), Human Resource Information System (HRIS), Human Resource System (HRMS), and virtual Human Resource (HR). There are few definitions given from several authors on EHRM. Oiry (2009) described EHRM as the application of Web technology in the HR practices and administrative policies. According to Voermans and van Veldhoven (2007), EHRM is referred to administrative support of HR functions in organizations by the application of internet technology. In addition, Ruel, Bondarouk and Looise (2004) describes EHRM as a tools in implementing HRM strategies, policies, and practices in organizations by providing conscious, directed support and full applications of web technology based channels. Besides, Strohmeir (2007) describes EHRM as the technology that helps both network and support tools for at least two individual or collective actors in their shared performing of HRM activities (Strohmeir, 2007). In addition, EHRM is referred to as the administrative support of the human resource function in organizations by the Internet technology's applications (Voermans \& Veldhoven, 2007). Bondarouk and Ruel (2009) claimed that EHRM definition of E-HRM is not standardized. Therefore, they came out with a new E-HRM definition to represent a consensus-based understanding of E-HRM. Bondarouk and Ruel (2009) described E-HRM as 'an umbrella term covering all possible integration mechanisms and contents between HRM and technologies aiming at creating value within and across organizations for targeted employees and management' (p. 507). The definition has covered four aspects which comprises of the content of EHRM, its implementation, targeted employees and managers, and the EHRM consequences. Since the aspects covered are conceptualized the whole idea of EHRM, this study attempt to adopt the definition of EHRM given by Bondarouk and Ruel (2009). Several of the previous studies have contributed to the knowledge about the consequences of E-HRM on various aspects. For instance, E-HRM towards HRM effectiveness (i.e., Bondarouk \& Ruel, 2005, 2009; Ruel, Bondarouk \& Velde, 2007; Sanayei \& Mirzaei, 2008); attitude on the use of E-HRM (i.e., Voermans \& Veldhoven, 2007; Yusliza \& Ramayah, 2011; Yusliza, Ramayah \& Haslindar, 2011); employee satisfaction towards EHRM (i.e., Gupta \& Saxena, 2011; Wickramasinghe, 2010); impact of EHRM on professional competence in HRM (i.e., Bell et al., 2006); and adoption of EHRM (i.e., Olivas-Lujan, Ramirez \& Zapata-Cantu, 2007; Panayotopoulou, Galanaki \& Papalexandaris, 2010; Strohmeier \& Kabst, 2009).

User Satisfaction: There have been several definitions offered for satisfaction. Bailey and Pearson (1983) and Wixom and Todd (2005) define satisfaction in a given situation as the sum of one's feeling and attitudes toward a variety of factors affecting the situation. More precisely, Oliver (1993) summarized the definition of satisfaction as the individual's emotional state following a certain experience. In the IS context, satisfaction is referred to as the recipient's reaction to the use of the output of an IS (Irani et al., 2012). In addition, end-user satisfaction is referred to as the IS end-user's overall affective and cognitive evaluation of the pleasurable level of consumption-related fulfillment experienced with the IS (Aggelidis \& Chatzoglou, 2012). In the present study, user satisfaction refers to the affective attitude towards a specific computer application by someone who interacts with the application directly (Doll \& Torkzadeh, 1988) by combining two roles: primary and secondary user roles. Limited studies were found that investigate the relationship between technostress, organizational IS-related support and user satisfaction, particularly in EHRM field (i.e., Tarafdar et al., 2011). However, the study was conducted in a Western country; the United States and the sample of the study were end users of information communication of technology (ICT), who worked at operational levels in middle-management positions in public sector. The results explained that end users' satisfaction was reduced due to technostress in handling ICT and organizational IS-related support was proven to increase the level of user satisfaction. In Malaysian context, a few studies have been conducted to capture the users' satisfaction in EHRM (i.e., MAMPU, 2011; McPherson \& Ramli, 2004; Mohd Azman, 2011; Noraswati, 2011). Therefore, the present study attempt to examine the user's satisfaction from a different context. 
Techno stress: Techno stress is any negative effect on human attitudes, thoughts, behavior, and psychology that directly or indirectly results from the use of computer-based ICTs (Tu et al., 2005). Wang et al. (2008) noted that Craig Brod defined the term technostress as "a modern disease of adaptation caused by an inability to cope with the new computer technologies in a healthy manner". Then, Weil and Rosen expanded and presented a new definition of technostress as "any negative impact on attitudes, thoughts, behaviors or psychology caused directly or indirectly by technology". Wang et al. (2008) summarized and noted that technostress was a "reflection of one's discomposure, fear, tenseness and anxiety when one is learning and using computer technology directly or indirectly, that ultimately ends in psychological and emotional repulsion and prevents one from further learning or using computer technology". Five conditions were highlighted by Tarafdar et al. (2007) that link with the use of technology and it is categorized as stressors associated with the use of technology. The stressors are techno-overload, techno-invasion, techno-complexity, techno-insecurity, and techno-uncertainty. Technooverload is referred to a situation when managers tend to communicate more information than is necessary and obtain more information than they can effectively process and use. Besides, technoinvasion can be described as the feeling of never can be escaped from technology. The users think that they are under surveillance and their lives have been overrun. Techno-complexity on the other hand would affect users to have spent more time to learn ICT. The end users would feel the variety of eapplications and functions are constraining them and they are unable to understand why and how to use it. With regard to techno-uncertainty, end users need to keep update with the changes in the applications and functions because the systems are continuously upgraded and improved. Finally, with regard to the techno-insecurity, end users feel threatened about their current jobs to be passed to other people who possessed better technology skills and knowledge than them. All these stressors may have impacted toward their satisfaction in using ICT. Furthermore, existing studies have validated, investigated and interpreted the phenomenon of technostress in various fields (Ayyagari et al., 2011; Bradshaw \& Zelano, 2013; Lee et al., 2012; Ragu-Nathan et al., 2008; Raja Zirwatul Aida, Azlina \& Siti Balqis, 2007; Salanova et al., 2012; Sami, 2006; Shepherd, 2004; Tarafdar et al., 2011; Tarafdar et al., 2007; Tarafdar et al., 2011; Tu et al., 2005; Ungku Norulkamar et al., 2009; Wang \& Shu, 2008; Wang et al., 2008). However, relatively few studies in information system (IS) literature provide evidence on the influence of technostress on user satisfaction towards certain computer systems applications.

Organizational IS-related Support: In the present study, organizational IS-related support consists of literacy facilitation, technical support provision, technology involvement, and innovation support. Tarafdar et al. (2011, pp. 118-119) have referred to these four organizational IS-related supports as inhibiting mechanisms of technostress which, at the same time, increase satisfaction towards IS. Literacy facilitation refers to the "mechanisms that educate through sharing of IS-related knowledge". Training and documentation are two examples that can be used by an organization to increase IS related awareness. The technical support provision is defined as the "assistance and technical support provided to professionals in the context of their use of IS". For instance, a quick-response and effective help desk can help users in using and becoming familiar with the system. Technology involvement facilitation describes "mechanisms that keep professionals involved in information system adoption and development". The involvement of users in the planning and implementing processes will help them to be familiar with a new system and reduce the techno-complexity, enhancing satisfaction. Innovation support describes "mechanisms that encourage professionals to experiment and learn". This mechanism requires management to take several actions such as, promoting supportive relationships among employees, facilitating communication and discussion, encouraging new ideas and providing incentives for learning. All the actions might help users to be more innovative and explorative in using the IS. Various studies have examined the effect of organizational support related to IS on user satisfaction and implementation of IS (Doll, 1985; Dong et al., 2009; Hartwick \& Barki, 1994; Jarvenpaa \& Ives, 1991; Lee et al., 2009; Mahmood et al., 2000; Mark et al., 2012; Ragu-Nathan et al., 2008; Rouibah et al., 2009; Sabherwal et al., 2006; Sanchez-Franco, 2009; Tarafdar et al., 2011; Thong et al., 1996).

The Proposed Research Framework and Hypotheses: Based on the explanation of user satisfaction, technostress, and organizational IS-related support and its dimensions in Literature Review, a research framework is presented in Figure 1. The research framework of the present study is adapted from the work of Tarafdar et al. (2011). Figure 1 depicts that technostress and organizational IS-related support influence user satisfaction towards HRMIS. 
Figure 1: Proposed research framework

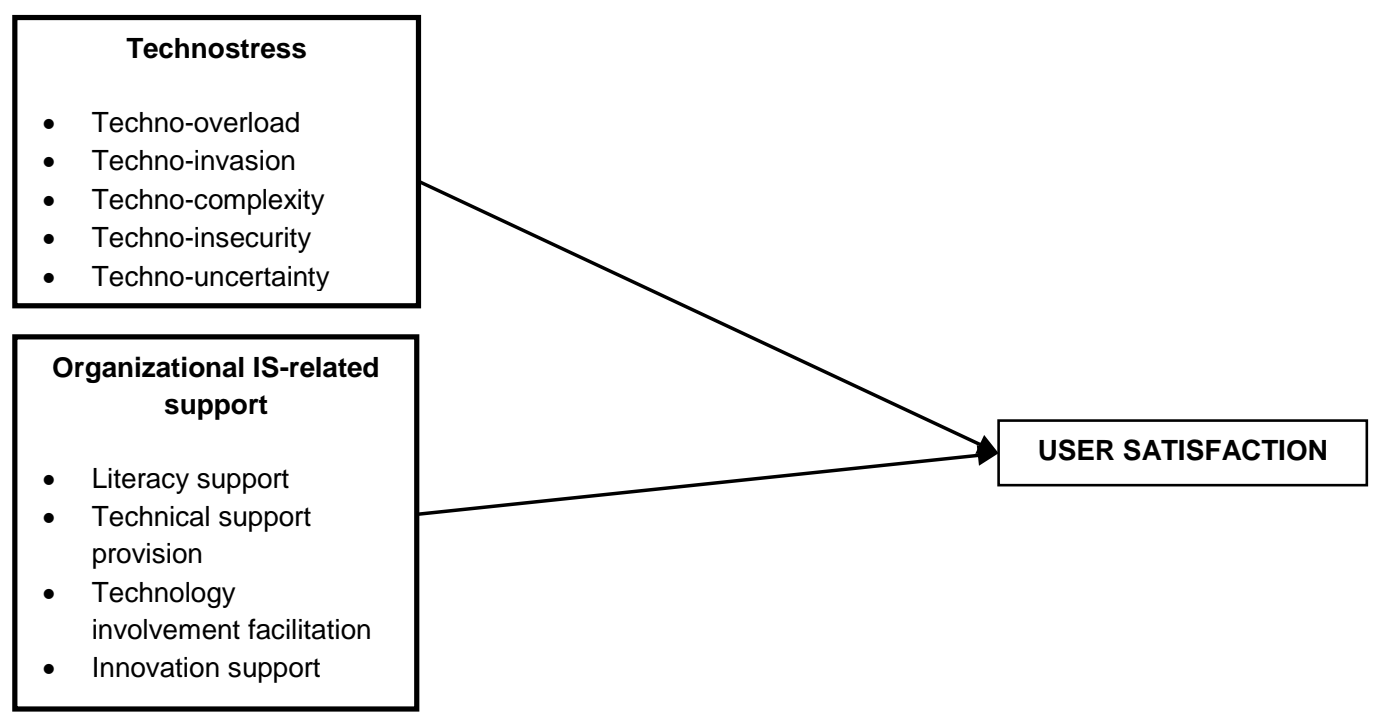

The applications subjected to continuous improvement to maintain its performance, fulfil new requirements, and simplify process of work. Technology applications at workplace always cause stress among the employees (Cooper, Dewe \& O'Driscoll, 2001). Stress related with technology, or called as technostress exists when the users faced problems using the systems or applications and unable to find solutions and get used to the technologies in a healthy manner (Ragu-Nathan et al., 2008). The technostress has five dimensions, which comprises of techno-overload, techno-invasion, technocomplexity, techno-insecurity and techno-insecurity (Ragu-Nathan et al., 2008). Based on the five dimensions of technostress, supervisors or superiors of employees tend to communicate more information to the employees than is necessary and they need to utilize the information to process and applied effectively. Higher technostress results in more dissatisfaction among end users on the systems they used (Ragu-Nathan et al., (2008). Several studies have confirmed that these situations have brought a significant negative impact on work outcomes such as job satisfaction, organizational commitment, innovation, productivity, and performance (Lee et al., 2012; Sami, 2006; Tarafdar et al., 2011; Tarafdar et al., 2007; Tu et al., 2005; Ungku Norulkamar et al., 2009; Wang et al., 2008). In fact, a few studies have identified a negative effect on end-user satisfaction (Tarafdar, Tu \& Ragu-Nathan, 2011; Tarafdar, Tu Ragu-Nathan et al., 2011).

Many of the previous studies have reported a positive relationship between organizational support and user satisfaction. However, a few studies have presented inconsistency evidence to support the relationship between the variables (Dong et al., 2009; Hwang \& Schmidt, 2011; Mark et al., 2012). Therefore, further investigation should be conducted to confirm the relationship between organizational support and user satisfaction. Moreover, a study conducted by Ragu-Nathan et al. (2008) has developed and validated a new instrument and terms of organizational support or inhibiting mechanisms, namely, literacy support, technical support provision, technology involvement facilitation and innovation support. They suggest that future studies should further investigate the instrument on a larger scale. The effect of technostress and organizational IS-related support in an individual's satisfaction is an issue that has so far not been addressed adequately. Therefore, a continuous effort should be taken to identify the effects of technostress and organizational IS-related support at the workplace. Based on the above discussions, the following hypotheses are thus proposed in this study.

H1: Technostress (techno-overload, techno-invasion, techno-complexity, techno-uncertainty, technoinsecurity) is negatively related to user satisfaction.

H2: Organizational IS-related support (literacy support, technical support provision, technology involvement facilitation and innovation support) is positively related to user satisfaction.

\section{Methodology}

Ten pilot agencies for HRMIS implementation at government organizations will be selected as the sites for data collection. These agencies are Public Service Department (PSD), Kuala Lumpur City Hall (DBKL), the 
Ministry of Health, Department of Chief Minister of Sarawak, Department of Irrigation and Drainage (DID), Perbadanan Kemajuan Negeri Selangor (PKNS), Majlis Amanah Rakyat (MARA), Chief Executive of the Management Information System (SMPKE), Unit Administrative Modernization and Management Planning (MAMPU) and the Department of Veterinary Services (DVS) (Public Service Department, 2010). Therefore, the population of the study will be consisted of all HRMIS users in the ten pilot agencies. Survey questionnaires will be used to obtain the data. A drop of/pick up method will be used to distribute the questionnaire. Sample will be determined by using a probability proportionate stratified sampling and the stratums will be identified as pilot agencies. Items for technostress and organizational IS-related support will be adapted from Ragu-Nathan et al. (2008). Items for user satisfaction will be adapted from $\mathrm{Au}$ et al. (2008). All the items will be measured on a ranging from ' 1 '“strongly disagree" to '7' "strongly agree". Items for computer self-efficacy will be adapted from Compeau and Higgins (1995). Finally, data analysis will be done using Partial Least Squared (PLS) and Statistical Package for Social Sciences (SPSS).

\section{Conclusion}

With the absence of previous studies on EHRM, this study has presented an overview of EHRM, technostress, and organization IS-related support, and user satisfaction. In this study, two main hypotheses have been proposed as the antecedents of user satisfaction. The primary aim of the study is to provide useful insights into EHRM area, and guide the phenomenon of technostress and organizational ISrelated support, particularly in the HRMIS's implementation in Malaysian government's sector.

Acknowledgement: This paper is a part of larger research of EHRM and funded by a Short-Term Research Grant (304/PPAMC) from Universiti Sains Malaysia, Penang, Malaysia.

\section{References}

Aggelidis, V. P. \& Chatzoglou, P. D. (2012). Hospital information systems: Measuring end user computing satisfaction (EUCS). Journal of Biomedical Informatics, 45(3), 566-579. doi: 10.1016/j.jbi.2012.02.009.

Aladwani, A. M. (2003). A deeper look at the attitude-behavior consistency assumption in information systems satisfaction research. Journal of Computer Information Systems, 44(1), 57-63.

$\mathrm{Au}$, N. \& Ngai, E. W. T. (2008). Extending the understanding of end user information system satisfaction formation: An equitable needs fulfillmen model approach. MIS Quarterly, 32(1), 43-66.

Au, N., Ngai, E. W. T. \& Cheng, T. C. E. (2002). A critical review of end-user information system satisfaction research and a new research framework. Omega, 30(6), 451-478. doi: 10.1016/s03050483(02)00054-3.

Ayyagari, R., Grover, V. \& Purvis, R. (2011). Technostress: Technological antecedents and implications. MIS Quarterly: Management Information Systems, 35(4), 831-858.

Bailey, J. E. \& Pearson, S. W. (1983). Development of a tool for measuring and analyzing computer user satisfaction. Management Science, 29(5), 530-545.

Baroudi, J. J., Olson, M. H. \& Ives, B. (1986). An empirical study of the impact of user involvement on system usage and information system. Communication of the ACM, 29(3), 232-240.

Bell, B. S., Lee, S. W. \& Yeung, S. K. (2006). The impact of eHR on professional competence in HRM: Implications for the development of HR professionals. CAHRS Working Paper Series. Retrieved on July, 2013 from http://digitalcommons.ilr.cornell.edu/cahrswp/403 website:

Bhattacherjee, A. (2001). Understanding information systems continuance: An expectation-confirmation model. MIS Quarterly, 25(3), 351-370.

Bondarouk, T. \& Ruel, H. (2005). Does E-HRM contribute to HRM effectiveness? Results from a quantitative study in a Dutch Ministry. The 4th International Conference of the Dutch HRM Network, Enschede, The Netherlands.

Bondarouk, T. \& Ruel, H. (2009). Electronic Human Resource Management: Challenges in the digital era. The International Journal of Human Resource Management, 20(3), 505-514.

Bradshaw, R. \& Zelano, J. A. (2013). Exploring themes of technostress for end users working with hardware and software technology. Retrieved on July, 2013 from http://www.gcasa.com/conference/Singapore12/papers?Zelano-1.pdf

Cho, V., Cheng, T. C. E. \& Hung, H. (2009). Continued usage of technology versus situational factors: An empirical analysis. Journal of Engineering and Technology Management, 26(4), 264-284. doi: 10.1016/j.jengtecman.2009.10.003. 
Cooper, C. L., Dewe, P. S. \& O'Driscoll, M. P. (2001). Organizational stress: A review and critique of theory, research, and applications. Thousand Oaks, California: Sage.

Dastgir, M. \& Mortezaie, A. S. (2012). Factors affecting the end-user computing satisfaction. Business Intelligence Journal, 5(2), 292-298.

DeLone, W. H. \& McLean, E. R. (1992). Information systems success: The quest for the dependent variable. Information Systems Research, 3(1), 60-95.

Doll, W. J. (1985). Avenues for top management involvement in successful MIS development. MIS Quarterly, 9(1), 17-35.

Doll, W. J. \& Torkzadeh, G. (1988). The measurement of end-user computing satisfaction. MIS Quarterly, I2(2) 259-274.

Dong, L., Neufeld, D. \& Higgins, C. A. (2009). Top management support of enterprise systems implementations. Journal of Information Technology, 24, 55-80.

Eia, L. M. (2004). HRMIS and power: Seamless integration. Buletin EG-HRMIS, June 2004, 6-7. Retrieved on July, 2013 from http://www.eghrmis.gov.my/docs/pdf/buletin/2004/k1b132004.pdf website:

Gudigantala, N., Song, J. \& Jones, D. (2011). User satisfaction with Web-based DSS: The role of cognitive antecedents. International Journal of Information Management, 31(4), 327-338. doi: 10.1016/j.ijinfomgt.2010.10.009

Guimaraes, T. \& Igbaria, M. (1997). Client/server system suvvess: Exploring the human side. Decision Science, 28(4), 851-876.

Gupta, A. \& Saxena, S. (2011). Employees' satisfaction towards E-HRM in service organizations. Gurukul Business review, 7, 41-52.

Hartwick, J. \& Barki, H. (1994). Explaining the role of user participation in information system use. Management Science, 40(4), 440-465.

Hussain, Z., Wallace, J. \& Cornelius, N. E. (2007). The use and impact of human resource information systems on human resource management professionals. Information \& Management, 44, 74-89.

Igbaria, M. \& Nachman, S. A. (1990). Correlates of user satisfaction with end user computing. Information \& Management, 19(2), 73-82.

Irani, Z., Weerakkody, V., Kamal, M., Hindi, N. M., Osman, I. H., Anouze, A. L. \& Al-Ayoubi, B. (2012). An analysis of methodologies utilised in e-governmentresearch: A user satisfaction perspective. Journal of Enterprise Information Management, 25(3), 298-313.

Ives, B., Olson, M. \& Baroudi, S. (1983). The measurement of user information satisfaction. Communication of the ACM, 26(10), 785-793.

Jarvenpaa, S. L. \& Ives, B. (1991). Executive involvement and participation in the management of information technology. MIS Quarterly, 15(2), 205-227.

Karimi, J., Somers, T. \& Gupta, Y. (2004). Impact of environmental uncertainty and task characteristics on user satisfaction with data. Information Systems Research, 15(2), 175-193.

Larsen, T. J. (2009). A multilevel explanation of end-user computing satisfaction with an enterprise resource planning system within an international manufacturing organization. Computers in Industry, 60(9), 657-668. doi: 10.1016/j.compind.2009.05.004

Lee, S. J., Jin, S. H. \& Choi, B. J. (2012). The influence of technostress and antismart on continuous use of smartphones. The World Congress on Engineering and Computer Science, San Francisco, USA.

Mahmood, M. A., Burn, J. M., Gemoets, L. A. \& Jacquez, C. (2000). Variables affecting information technology end-user satisfaction: A meta-analysis of the empirical literature. International Journal Human-Computer Studies, 52, 751-771.

MAMPU. (2011). Kajian keberkesanan pelaksanan SMPC dan SMPT dalam pengurusan sumber manusia sektor awam. $\quad$ Retrieved $\quad$ on $\quad J u l y, ~ 2013$ from http://www.eghrmis.gov.my/docs/pdf/buletin/2011/laporan-brc.pdf website:

Mark, I. H., Cindy, T. L. \& Lin, J. W. (2012). Organizational factors for successful implementation of information systems: Disentangling the effect of top management support and training. The Southern Association for Information Systems Conference, Atlanta, GA, USA.

McGill, T. \& Klobas, J. (2008). User developed application success: Sources and effects of involvement. Behaviour and Information Technology, 27(5), 407-422.

McKinney, V., Yoon, K. \& Zahedi, F. M. (2002). The measurement of Web-customer satisfaction: An expectation and disconfirmation approach. Information Systems Research, 13(3), 296-315.

McPherson, M. \& Ramli, R. (2004). Lessons learned from the implementation of a Malaysia egovernment project. In M. Khosrow-Pour (Ed.), Innovations through information technology. USA: Idea Group Inc. 
Mohd Azman, M. A. (2011). The effects of task-technology fit on use and user performance impacts: The case of the human resource management information system in the Malaysia public sector. Retrieved on July, 2013 from http://www.pacis-net.org/file/2011/PACIS2011-010 website:

Nadkarni, S. \& Gupta, R. (2007). A task-based model of perceived website complexity. MIS Quarterly, 31(3), 501-524.

Noe, R. A., Hollenbeck, J. R., Gerhart, B. \& Wright, P. M. (2008). Fundamentals of human resource management ( $3^{\text {rd }}$ Ed.). New York: McGraw-Hill.

Noraswati, A. W. (2011). The effectiveness of Human Resorce Management Information System (HRMIS) application in managing human resource at the Perlis State Secretary Office. Master of Science (Information Technology), Universiti Utara Malaysia, Sintok, Kedah.

Norshita, M. N., Halimah, B. Z. \& Tengku Mohammad, T. S. (2010). Public user assessment of Malaysia's egovernment applications. World Academy of Science, Engineering \& Technology, 43, 813-817.

Olivas-Lujan, M., Ramirez, J. \& Zapata-Cantu, L. (2007). E-HRM in Mexico: Adapting innovativeness for global competitiveness. International Journal of Manpower, 28(5), 418-434.

Oliver, R. L. (1993). Cognitive, affective, and attribute bases of the satisfaction response. The Journal of Consumer Research, 20(3), 418-430.

Oliver, R. L. \& Richard, L. (1980). A cognitive model of the antecedents and consequences of satisfaction decision. Journal of Marketing Research, 17, 4460-469.

Panayotopoulou, L., Galanaki, E. \& Papalexandris, N. (2010). Adoption of electronic systems in HRM: is national background of the firm relevant? New Technology, Work and Employment, 25(3), 253269. doi:10.1111/j.1468-005X.2010.00252.x

Ragu-Nathan, T. S., Tarafdar, M., Ragu-Nathan, B. S. \& Tu, Q. (2008). The consequences of technostress for end users in organizations: Conceptual development and empirical validation. Information Systems Research, 19(4), 417-433.

Raja Zirwatul Aida, R. I., Azlina, A. B. \& Siti Balqis, M. N. (2007). Techno stress: A study among academic and non academic staff. The 2007 International Conference on Ergonomics and Health Aspect of Work with Computers, Berlin.

Rawash, H. N. \& Saydam, S. (2012). The Impact of Electronic Human Resource Management on Organization's Market Share : An Empirical Study on the Housing Bank for Trade and Finance in Jordan. International Journal of Business and Social Science, 3(24), 113-120.

Rouibah, K., Hamdy, H. I. \& Al-Enezi, M. Z. (2009). Effect of management support, training, and user involvement on system usage and satisfaction in Kuwait. Industrial Management and Data System, 103(9), 338-356.

Ruel, H. J. M., Bondarouk, T. V. \& Looise, J. K. (2004). E-HRM: Innovation or irritation. An explorative empirical study in five large companies on web-based HRM. Management Revue, 15(3), 364-380.

Ruel, H., Bondarouk, T. \& Velde, M. V. D. (2007). The contribution of e-HRM to HRM effectiveness: Results from a quantitative study in a Dutch Ministry. Employee Relations, 29(3), 280-291.

Sabherwal, R., Jeyaraj, A. \& Chowa, C. (2006). Information system success: Individual and organizational determinants. Management Science, 52(12), 1849-1864.

Sanayei, A. \& Mirzaei, A. (2008). Designing a model for evaluating the effectiveness of E-HRM (Case study: Iranian organizations). International Journal of Information Science \& Technology, 6(2), 79-97.

Sanchez-Franco, M. J. (2009). The Moderating Effects of Involvement on the Relationships Between Satisfaction, Trust and Commitment in e-Banking. Journal of Interactive Marketing, 23(3), 247258.

Schaupp, L. (2010). Web site success: Antecedents of web site satisfaction and re-use. Journal of Internet Commerce, 9(1), 42-64.

Shilpa, V. \& Gopal, R. (2011). The implications of implementing electronic-human resorce management (E-HRM) systems in companies. Journal of Information Systems and Communication, 2(1), 10-29.

Strohmeier, S. (2007). Research in e-HRM: Review and implications. Human Resource Management Review, 17, 19-37.

Strohmeier, S. \& Kabst, R. (2009). Organizational adoption of e-HRM in Europe: An empirical exploration of major adoption factors. Journal of Managerial Psychology, 24(6), 482-501. doi: $10.1108 / 02683940910974099$

Tarafdar, M., Pullins, E. \& Ragu-Nathan, T. S. (2011). Examining impact of technostress on the professional sales person's performance. The AMCIS 2011 Proceedings, Michingan, United States.

Tarafdar, M., Tu, Q. \& Ragu-Nathan, T. S. (2011). Impact of technostress on end-user satisfaction and performance. Journal of Management Information Systems, 27(3), 303-334.

Tarafdar, M., Tu, Q., Ragu-Nathan, B. S. \& Ragu-Nathan, T. S. (2007). The impact of techno stress on role stress and productivity. Journal of Management Information Systems, 24(1), 301-328. 
Tarafdar, M., Tu, Q., Ragu-Nathan, T. S. \& Ragu-Nathan, B. S. (2011). Crossing to the dark side: Examining creators, outcomes, and inhibitors of technostress. Communication of the ACM, 54(9), 113-120.

Thong, J. Y. L., Yap, C. S. \& Raman, S. (1996). Top management support, external expertise and information system implementation in small businesses. Information Systems Research, 7(2), 248-267.

Tu, Q., Wang, K. L. \& Shu, Q. (2005). Computer-related technhostress in China. Communications of the ACM, 48(4), 77-81.

Ungku Norulkamar, U. A., Salmiah, M. A. \& Wan Khairuzzaman, W. I. (2009). The impact of technostress on organisational commitment among Malaysian academic librarians. Singapore Journal of Library \& Information Management, 38(2).

Venkatesh, V., Morris, M., Davis, G. \& Davis, F. (2003). User acceptance of information technology: Toward a unified view. MIS Quarterly, 27(3), 425-478.

Voermans, M. \& Veldhoven, M. V. (2007). Attitude towards E-HRM: An empirical study at Philips. Personnel Review, 36(6), 887-902.

Wang, K. \& Shu, Q. (2008). The moderating impact of perceived organizational support on the relationship between technostress and role stress.

Wang, K., Shu, Q. \& Tu, Q. (2008). Technostress under different organizational environments: An empirical investigation. Computers in Human Behavior, 24, 3002-3013.

Wang, Y. S., Tang, T. I. \& Tang, J. T. (2001). An instrument for measuring customer satisfaction toward web sites that market digital products and services. Journal Of Electronic Commerce Research, 2(3), 89-102.

Wickramasinghe, V. (2010). Employee perceptions towards web-based human resource management systems in Sri Lanka. The International Journal of Human Resource Management, 21(10), 16171630. doi:10.1080/09585192.2010.500486

Wixom, B. H. \& Todd, P. (2005). A theoretical integration of user satisfaction and technology acceptance. Information Systems Research, 16(1), 85-102.

Yusliza, M. Y. \& Ramayah, T. (2011). Factors influence attitude towards using electronic HRM. The 2nd International Conference on Business and Economic Research, Kedah, Malaysia.

Yusliza, M. Y., Ramayah, T. \& Haslindar, I. (2011). HR roles and E-HRM: Some initial evidence from Malaysia. International Journal of Current Research, 3(2), 131-138. 